\title{
TAMING TEXTS OF TERROR: READING (AGAINST) THE GENDER GRAIN OF 1 TIMOTHY
}

Gerald West

School of Theology

University of KwaZulu-Natal

\begin{abstract}
Do texts have ideological grain, and if so, can we read against this grain? This question lies at the heart of this article. Even those biblical scholars from interpretative traditions that have emphasized the liberatory character of the Bible have had to admit that there are some biblical texts that are oppressive. 1 Timothy 2:8-15 is one such text. Using a case study from the field of oral history, the article examines the effects of 1 Timothy 2:8-15 on the leadership of women in a particular local church in Malawi. The article then goes on to examine how this text sustains its patriarchal ideological grain so many centuries after it was written. The article concludes by analyzing a number of attempts to tame this text of terror, and reflecting on the public role of the socially engaged biblical scholar.
\end{abstract}

\section{Introduction}

Some years ago Elsa Tamez, a biblical scholar and social activist from Costa Rica, made the comment that Latin American biblical scholars would have to face up to the fact that there were biblical texts that resisted being read liberatively. One of the great contributions of Latin American biblical scholarship has been its resolute commitment to reading the Bible as a liberatory text (see Vaage, 1997, Hanks, 2000). While not questioning this contribution or orientation, Tamez was worried that she and her colleagues were sidestepping significant hermeneutical issues by not taking seriously those texts that seemed to have an anti-liberation ideological agenda (or grain). Her comment arose from seeing my little book on Contextual Bible Study (West, 1993) in which I try to come to grips with the text of 1 Timothy from a gendered perspective. She herself, she told me, was working on 1 Timothy for the very same reason. What do those of us who are committed to God's project of liberation for women do with texts like 1 Timothy 2:8-15 and what hermeneutical questions does this generate?

\section{Ideological Grain}

Itumeleng Mosala has a ready answer: "Oppressive texts cannot be totally tamed or subverted into liberative texts", he argues (Mosala, 1989a:30). Why? Because they have ideological grain. Drawing on the work of Terry Eagleton and Norman Gottwald, Mosala presents a passionate case for the graininess of texts. "The impotence of black theology as a weapon of struggle comes from this useless sparring with the ghost of the oppressor, whom black theology has already embraced in the oppressor's most dangerous form, the ideological form of the text" (Mosala, 1989a:28). While Mosala accepts that "texts that are against oppressed people may be co-opted by the interlocutors of the liberation struggle", he insists that "the fact that these texts have their ideological roots in oppressive practices means that the texts are capable of undergirding the interests of the oppressors even when 
used by the oppressed. In other words, oppressive texts cannot be totally tamed or subverted into liberative texts" (Mosala, 1989a:30).

The Bible, according to Mosala's analysis, is a complex text best understood as a "signified practice". "It cannot be reduced to a simple socially and ideologically unmediated "Word of God". Nor can it be seen merely as a straight forward mirror of events in biblical times. On the contrary it is a production, a remaking of those events and processes" (Mosala, 1989b:3). Using the language of redaction criticism, Mosala argues that the different "layers" historical-critical work detects each have a particular ideological code. Some layers of the Bible are cast in "hegemonic codes", which represent social and historical realities in ancient Israel in terms of the interests of the ruling classes. Other parts of the Bible are encoded in "professional codes", which have a relative autonomy, but which still operate within the hegemony of the dominant code. Then there are layers that are signified through "negotiated codes", which contain a mixture of adaptive and oppositional elements, but which still take the dominant codes as their starting point. Finally, there are a few textual sites that represent "oppositional codes" which are grounded in the interests and religious perspectives of the underclasses of the communities of the Bible (Mosala, 1989a:41-42).

A critical and structural analysis of the biblical text requires that black theology identify the ideological reference-code in which a particular text is encoded. For it is only by recognizing the particular ideological encoding of a text that an interpreter can prevent herself or himself from colluding with the dominant and hegemonic. Moreover, it is only by recognizing the particular encoding of a text that the interpreter can then interpret the text "against the grain".

The concern of Mosala is not that black theologians cannot read any text, no matter what its encoding, against the grain, but that they ought not to do this without recognizing what they are doing. The danger, Mosala warns, is that apparently tamed texts may come back to hurt and haunt us.

\section{Texts that Resist Taming}

A good example of Mosala's point is captured in the incident Isabel Phiri recounts in a case study from Malawi (Phiri, 2000). The case study centers around the ministry of Mercy Yami (Phiri, 2000:279-288), who was born in Harare, Zimbabwe, of Malawian parents in 1950. Phiri charts Yami's story from her childhood days in the Providence Industrial Mission church in Malawi to her becoming Bishop of her own church. Among her many ministries, Bishop Yami worked among rural women, with a particular focus on "reaching out to blind people" (Phiri, 2000:285). It was while she was engaged in this work that she met Pastor Lumwira. Pastor Lumwira had been converted in prison, and while seeking direction from God after having completed his prison sentence, "God told him to team up with Bishop Yami”, before he had even met her (Phiri, 2000:285). When they did meet, there was a mutual recognition of God's providence "and both had the conviction that they should join their ministries" and establish the Blessed Hope Church (Phiri, 2000:285). Phiri notes, importantly, that "Bishop Yami became the office director while Pastor Lumwira was the field director" (Phiri, 2000:285).

Some months after the interviews that formed the basis of her account of the ministry of Bishop Yami, and some months after the formation of the Blessed Hope Church under the joint leadership of Bishop Yami and Pastor Lumwira, something quite extraordinary took

1. I have discussed these issues more fully in (West, 2000b, West, 2002a, West, 2002b). 
place, and I quote Phiri in full at this point.

Despite the fact that Pastor Lumwira says he was guided by God to team up with Bishop Yami[,] the partnership did not survive after our first visit to interview him. In November 1995, Pastor Lumwira wrote a letter to Bishop Yami informing her that it is not Biblical for a woman to become leader of a church. Therefore he asked that she should resign. A meeting of ten people was set up to discuss the issue with the two leaders. No agreement was reached. Bishop Yami left the Blessed Hope Church (Phiri, 2000:286).

Fortunately, this was not the end of Bishop Yami's ministry, and Phiri goes on to describe her work in some detail. Of particular significance for my paper is the Bible's role in Pastor Lumwira's call for Bishop Yami to resign. Phiri has elaborated, in her discussions with me concerning this case study, on Pastor Lumwira's biblical rationale. In her first series of interviews with Pastor Lumwira, having noted his claim that God had called him to work with Bishop Yami and having noted their successful joint leadership of the Blessed Hope Church, Phiri probed Pastor Lumwira about biblical texts, specifically 1Timothy 2:815 , and how he interpreted them. Phiri's intent was clearly to discover the kind of biblical hermeneutics that allowed Pastor Lumwira to "tame" a biblical text that argues against women taking leadership positions in the church. What appears to have happened, however, is that Phiri's questions aroused this text from its slumber; once awoken, it beared its teeth and devoured Bishop Yami! Having been alerted to this text by Phiri, it would appear (Phiri, 2000:286), Pastor Lumwira was prompted to reexamine this text and then to conclude that the text overruled God's call to his work with Bishop Yami, a woman.

Mosala, it would appear, has a point!

\section{Do Texts have Grain?}

However, I do not want to concede Mosala's point without nuancing it. Mosala's argument assumes that texts have ideologies, is this an unproblematic assumption? In a carefully argued article Stephen Fowl considers such questions. Recognizing that "ideological criticism" has become an accepted practice within biblical studies, he sets out to problematize the claim that the Bible or a biblical passage has an ideology (Fowl, 1995:15). He begins by demonstrating that those who make such claims usually make two moves. Their initial move is to argue that "those who produced the biblical texts shaped them in the light of their own economic, ethnic, social or gender based interests". They then go on to say that "the racism, androcentrism or elitism of the people who produced the text is a property of it. Hence, the text has an ideology". In support of his argument Fowl cites Mosala's work: biblical texts, "as products, records and sites of social, historical, cultural gender racial and ideological struggles ... radically and indelibly bear the marks of their origins and history. The ideological aura of the Bible as the Word of God conceals this reality" (Mosala, 1989a:20, cited in Fowl, 1995:15, note 2).

Fowl's article takes issue with these claims, "arguing that speaking of the Bible (or any text) as having an ideology introduces a whole range of conceptual confusions and fails to take seriously the varied history of Bible interpretation" (Fowl, 1995:16). He immediately qualifies this statement by noting that he cannot "demonstrate that texts do not have ideologies"; his assignment in this article is more modest. What he hopes to show, and he succeeds in doing this, is that "if one insists on talking as if texts have ideologies, then one also has to hold a whole range of other inelegant, awkward or incoherent positions. Furthermore, dropping the idea that texts have ideologies will allow us to think in clearer more productive ways about particular texts, about the relationships between texts and social practices and about how one might alter the social practices underwritten by 
particular texts (especially biblical texts)" (Fowl, 1995:16).

Drawing on an earlier article in which he examines what it means to speak of a text having "meaning" (Fowl, 1990), Fowl asks whether it makes sense to speak of ideology as a property of a text. Such thinking, he argues, assumes that the text "is viewed as a relatively stable element into which an author inserts, hides or dissolves (choose your metaphor) ideologies and meanings, and the task of the critic or reader is to dig out, uncover or distill these properties from it" (Fowl, 1995:16). But there are a number of problems with this way of thinking. First, there has to be some agreement on what we are looking for when we look for ideologies. This is not a substantial problem, as "ideology" is less slippery than "meaning". Fowl's working definition of "ideology", for example, would be quite acceptable to Mosala: ideology "as a consensual collection of beliefs, attitudes, and convictions that is related in certain specifiable ways to a whole range of social, political, and material artifacts and practices" (Fowl, 1995:17, see also West, 1995:251, note 7). But agreement on what we understand by "ideology" "does not entail that texts have ideologies" (Fowl, 1995:17).

A second, more serious, problem is that "over its life a text can be pressed into the service of so many varied and potentially conflicting ideologies that talk about a text having an ideology will become increasingly strained" (Fowl, 1995:18). Fowl carefully illustrates this point by providing a history of interpretation of the story of Abraham. As the Abraham story is read in a range of different socio-historical contexts, so the ideological interests that shape and are shaped by each reading shift. Philo puts the story of Abraham to quite different ideological purposes to those of tribal Israel; Paul's reading reflects and is related to a whole range of ideological interests in his context; and when we compare Justin Martyr's interpretation with that of Paul's we find a different set of socio-political and theological interests. Clearly, says Fowl (1995:28), the question that persists as we reflect on these various ideological interpretations is this: which is the ideology of the text?

Mosala would respond quite quickly, I think, stating that it is the ideological interests and aims at work in the production of a text that constitute the ideology of the text. Texts get their grain from the ideological the sites that produced them. ${ }^{2}$ Fowl anticipates such a response, and counters by asking why one would want to privilege this particular moment in a text's history (Fowl, 1995:29). This is a good question, and posing it is one of Fowl's considerable contributions to clarifying what is going on in biblical interpretation. However, convincing as I find Fowl's arguments, what about texts like 1 Timothy 2:8-15 and its ongoing effects on Pastor Lumwira? Why is it that this text cannot be tamed?

\section{The Grain of a Text of Terror}

These are good questions and attempting to answer them is instructive. First, following Fowl's line of argument, we might argue that texts such as 1 Timothy embody their sites of production more clearly than other kinds of texts. This is a plausible argument, given that the letter genre does mark a text's origins in a way that other genres (for example, narrative texts) do not. Every time we read 1 Timothy we are reminded by its formulaic beginning and ending that it is a letter written by a particular person to particular persons dealing with particular issues in a particular context. So the context of production is ever present, even if we do not always comprehend the details of that context.

2. As my discussion of Mosala's work indicates, Mosala would accept the plurality of ideologies in a text; while what Mosala means by this is primarily a series of layers of differing ideologies, a more nuanced analysis would insist on there always being more than one ideology within any particular layer. 
Second, and here we would have to reject some of Fowl's argument, we may argue that contexts of production always leave a trace of their ideological struggles in the very literary fabric of the text. In cases where texts make clear ideological statements this would seem to be fairly self-evident. The ideological perspective of 1 Timothy 2:8-15 concerning women is of this kind. There are unambiguous statements which construct a clear patriarchal hierarchy. These clear statements have made it very difficult for even the most wellintentioned rescuers of 1 Timothy to ignore this ideological grain (see Hanks, 2000:169170). This does not mean that there are not other resources within 1 Timothy that might enable readers with a different ideological perspective to partially deconstruct these statements (see below), but these statements do stand defiantly against most attempts. And, as we have seen with Pastor Lumwira, these clear ideological statements do have the power to overturn a theology that had plenty of place for women in leadership.

Third, on a less overt level, we may want to argue that the reason 1 Timothy remains a text of terror for women is that in addition to these clear statements, the text is saturated with androcentric "voice." This notion - that biblical texts have a gendered voice and that this voice can be detected - was pioneered by feminist biblical scholars Athalya Brenner and the late Fokkelien van Dijk-Hemmes. Controversial at the time, Brenner and van DijkHemmes persisted with this quest and produced their landmark book On gendering texts. Female and male voices in the Hebrew Bible (Brenner and van Dijk-Hemmes, 1993). Ten years later, at a conference here in South Africa, Brenner looked back on this project and articulated her doubts about it. "I was not and am not satisfied with the positively triumphant diagnosis of either female or male voices in the text." The problem, she says (and here she follows Fowl), is that "The reader's ideology intervenes here: questions put to the text, so to speak, will largely determine the answers teased from it. Gender ideology, in that respect, is no different from any other ideology" (Brenner, 2002:44). Her doubts about an objective determination of gendered voice have not meant that she has abandoned the quest. For her "the project for looking for textual female 'voices' ... has always been and still is worthwhile. The mere contemplation of a biblical passage as a reflection of a female voice - be the reflection distorted as it may, within the male-authored envelope strangulating and oppressing it - is important and satisfying, certainly subversive of accepted and conventional wisdom" (Brenner, 2002:44). The project has not changed, but the methodology has, shifting much more self-consciously to the reader. Her own methodological solution "calls for two hypothetical gender readings of each text that may allow it (including passages attributed to women in / by the biblical text). In practice this requires that the reader,

Read a suitable text as if it contains a female voice or voices, including pronounced stereotypes of the other gender and subversive traits, according to the methodological criteria you adopt and your own reading needs; see how far such a gendered reading can help you resolve textual difficulties as well as interpretive or theological issues. See how much, if at all, you can gain (Brenner, 2002:45).

We will return to Brenner's imaginative reading methodology in the next section, but before we do, it is worth noting that even those who have not read Fowl's article on textual ideology have come to similar conclusions, albeit by different routes. Being suspicious of the confident claims by scholars to be able to determine the biblical author's [or texts'] intention, doubting that women, who have internalised the dominant voices and demands of the dominant culture they live in, are able "to define their own 'authentic' female concerns, or voices," and in keeping with modern and postmodern theories about readers' reception (Brenner, 2002:45), Brenner turns resolutely to the ideology of the reader. 
So it looks as if we will have to let go of the notion that texts have a clearly determinable ideology, except perhaps in the senses I have suggested in points one and two above. But this does not stop biblical scholars reading texts as if they do have ideologies! In his interesting work on "the ideology of writers and readers of the Hebrew Bible," David Clines explicitly acknowledges Fowl's arguments as valid, but then goes on to say that he will "not promise to resist the way of the world on either account," that is, that texts and readers have ideologies (Clines, 1995:17, note 17). True to his claim, Clines goes on to offer a number of fascinating readings of the ideologies of Hebrew Bible texts, assuming that their ideologies are somehow embedded in their literary being. To be fair to him, having determined their predominant ideological grain, he usually goes on to deconstruct it by using the text itself against this ideology (and in so doing somewhat undermines his determination of their ideological grain). Clines is not unaware of this contradiction. In another essay in the book from which I have quoted Clines elaborates on his practice (and again he is dialoguing with Fowl):

Strictly speaking, texts do not have grains any more than they "have" meanings. Authors would like to put grains in their texts, of course, and readers are forever finding grains in texts, even though they are not there. But since authors do not own their own texts, not forever, authors' intentions do not constitute the reality of the texts they compose or determine their meaning. And from the readers' side, what counts as the grain of the text for them is no more than what some interpretative community or other decides to call the grain. So when I am reading against the grain, I am really reading against the practice of an interpretative community, sometimes even against myself and my own first reading. Strictly speaking, the text is not to blame for the thoughts that come into my head when I am reading it, but I am not always speaking strictly; like most people, in everyday speaking and writing I go on ascribing meaning and grain to texts (Clines, 1995:207, note 38).

I have quoted Clines at length because he provides me with all the ingredients I need to summarise this section of my article. First, he underscores how problematic it is to talk of texts having grain, though he minimises, I think, Mosala's claim (acknowledged by Fowl) to texts having grain when (and if) we focus on socio-historical context of production. I have drawn attention to this claim in the case of 1 Timothy because this text seems to carry its context of production along with it in a way that many other texts do not. I suggested that its overtly patriarchal propositions and its literary form probably play a role in this. Second, Clines acknowledges how difficult it is not to talk about texts having grain! This leads to my third and final point. Clines reminds us of the considerable power and durability of an interpretative community. In the case of 1 Timothy we see the power of an emerging androcentric interpretation of Genesis 2-3, initially proposed by this text and then taken up by centuries of ecclesiastical interpretation. Here there is real grain! The grain of the history of interpretation of 1 Timothy 2:8-15 is unambiguously against women, and so it should not surprise us that it takes considerable effort and perseverance to read against this grain.

\section{Attempts to tame 1 Timothy 2:8-15}

Many thousands of ordinary African Christians in Malawi have found their own ways of taming this text, in the sense that their "working" theologies allow for women in leadership. What makes the case of Pastor Lumwira particularly disturbing is that this text had the power to overturn his more inclusive working theology (and the call of God). Clearly, the text remains a problem, which is why biblical scholars with a commitment to women's liberation have made various attempts at taming this text of terror. In what follows I will 
present three methodologically different attempts to do this. Importantly, the examples given below have been used extensively in work between socially engaged biblical scholars and ordinary black African readers (whether literate or not) of the Bible. The Institute for the Study of the Bible and Worker Ministry Project, located in the School of Theology at the University of Natal, has regularly used these examples in contextual Bible studies (West, 1993: chapter 3). They have had a measure of success in the ten years we have been using these readings as the basis for Bible studies.

One memorable case of (at least partial) success was in the Amawoti community. The Institute for the Study of the Bible and Worker Ministry Project worked for many years in the Amawoti informal settlement on the outskirts of Durban with two local organisations: Funda Wenza, a women's group (with links to the Ilimo primary health care project) and the Amawoti Ministers Organisation (AMO), an association of ministers from various African Independent Churches. One of the themes discussed and workshopped with participants from these organisations had to do with women and leadership. 1 Timothy 2:815, along with a number of other texts (for example, Mark 5:21-6:1; (see Sibeko and Haddad, 1997)) were workshopped using the contextual Bible study method (West, 2000a). At the end of the year, having worked with the community on every alternative Saturday throughout the year, the participants requested that the ISB \& WM "examine" them. They argued that they wanted to give additional weight to the attendance and participation certificate we awarded them by being orally examined by a panel of examiners. We agreed, and it was during these oral examinations that it became clear that our contextual Bible studies on 1 Timothy 2:8-15 had a profound effect on almost all the participants. Participant after participant stated that this had been one of the Bible studies that had most changed their normal perspective and practice. For example, one male minister explained that this Bible study (together with the Bible study on Mark 5:21-6:1, which focussed on the woman with a flow of blood who is healed by Jesus) had changed his view of his wife's role in the church (though he was less sure about whether it ought to change his view on his wife's role in the home). As far as the church was concerned, he recognised that she ought to have an equal role there, and this included allowing his wife to participate fully in these fortnightly Bible study workshops with him. It also included setting up a desk in their home, next to his, where she could study.

So we have had some success in taming these texts. The resources we have used are a collaborative combination of the resources of biblical scholarship and the local "reading" resources of local Christian communities. I will now briefly discuss the kind of scholarly contribution we offered (not as expert input, but in the form of directive questions).

My first example of scholarly attempts to tame this text places its focus on the sociohistorical dimensions of the text. A number of biblical scholars have tried to tame this text by locating the text as clearly as they can within its socio-historical context (see Draper, 1991, on whose work most of what follows is based). 1 and 2 Timothy and Titus are widely accepted to have been written late in the first century, or even the beginning of the second century, in the name of Paul (but not by Paul himself). By this time the egalitarian and inclusive ethos of the early Jesus movement, which maintained equality between Jew and Gentile, slave and free, and male and female, was becoming compromised as the church became more and more like the patriarchal Greco-Roman society around it. In fact, it seems as if 1 Timothy is explicitly concerned to counter some of the inclusive and egalitarian tendencies of the early Jesus movement in order to make the church conform to and therefore be acceptable to the societal status quo. While the early Jesus movement was in conflict with the dominant world view, the emerging early church in 1 Timothy seeks to accommodate itself to the dominant world view in order to be acceptable to it. 
The central concern of 1 Timothy is to construct the church according to the order and hierarchy of the patriarchal Greco-Roman household. "God's household" (3:15) is patterned on the Greco-Roman household. The position of the bishop in the church is made parallel to the position of the male patriarch in a Greco-Roman household. Subjects must be in submission to the emperor and civil officials (2:1-7); women must be in submission to men (2:8-15); the youth must be in submission to their elders (5:1-4); and slaves must be in submission to masters $(6: 1-2)$.

The extended argument concerning women indicates that this was a particularly contentious issue in the community $(2: 9-15 ; 5: 3-16)$. Women must have been actually teaching and exercising leadership in the church at this time, because the writer goes to great lengths to counter this practice with detailed scriptural and theological argumentation. In conformity with the dominant Graeco-Roman practice at that time, the role of women in 1 Timothy is prescribed as being primarily in the home in submission to the male head of the household. Further, in public worship in the church women are to dress modestly, to remain silent, to receive instruction passively from men, and to do good deeds under the control of the male leaders of the church.

To compound matters, this patriarchal perspective on women is theologically legitimated by a male reading of the creation story $(2: 13-15)$, and this reading has dominated thinking in the church for centuries.

A socio-historical reading of 1 Timothy presents us with a picture of women in the church towards the end of the biblical period. The church, which was initially subversive in its context, has in 1 Timothy compromised with its context. Women are no longer coworkers with Christ as they were in the early Jesus movement; they are now to be constrained in their ministry by the norms of patriarchal society. A socio-historical reading helps us to locate and situate the concerns of 1 Timothy and in so doing assists us to tame this text and so to appropriate this text critically.

The egalitarian and inclusive vision and practice of the early Jesus movement have been compromised but not completely forgotten, it can be argued. The subversive vision and practice of Jesus (in the gospels, particularly John) and Paul (in Galatians 3:26-29 and to some extent in 1 Corinthians 7:8-16) are still remembered and practised in the church of 1 Timothy, even if they are being countered. While we have to acknowledge that the trend towards conformity to the patriarchal status quo can be seen in Colossians, Ephesians, 1 and 2 Timothy, and Titus, fortunately this is not the whole story. The egalitarian and inclusive impulses and practices of the early Jesus movement have the potential to explode male domination today just as they had then.

My second example comes from those biblical scholars who focus on the literary dimensions of the biblical text. Some scholars, and the pioneer here is Phyllis Trible, have chosen to tackle texts like this from a literary perspective. A careful and close reading of 1 Timothy from the perspective of women would concentrate on those passages which concern women, particularly 2:8-15.

This text consists of two related parts. In verses 9-12 (and 15) the writer presents his perspective and practice on the role and function of women. In verses 13-14 he offers biblical support for his position. From a literary perspective, a careful reading of verses 812 makes it clear that the point of view given is that of the writer. The subject is "I". This is not God speaking but a male human being. This is an important recognition in our reading. However, the real problems arise in the second section.

A close reading of verses 13-14 makes it clear that the writer's biblical reading is wrong or inappropriate. The writer of 1 Timothy argues: "For Adam was formed first, then Eve. 
And Adam was not the one deceived; it was the woman who was deceived and came into transgression". Even a cursory reading of Genesis 3 clearly indicates that both the man and the woman were deceived and that both transgressed. The actions of the man in 3:6-12 and the actions of God in 3:17-19 make this abundantly clear. Both the man and woman are responsible before God. So the second argument of the writer of 1 Timothy ("And Adam was not the one deceived; it was the woman who was deceived and came into transgression") is obviously wrong.

A careful reading of Genesis 2:4-25 (and here I am drawing on the work of Trible (1979)) also raises doubts about the first argument: "For Adam was formed first, then Eve". Genesis 2:7 does not say that God created a male! It says that God created "the ha-adam of the dust of the ha-adama." The text clearly draws our attention to the similarity between these Hebrew words. How are we to interpret this? Both are common nouns, not proper nouns or names; they are preceded by $h a$ which is Hebrew for the definite article ("the"). We usually translate ha-adama as "the earth." Should we not then, as women interpreters have suggested, translate ha-adam as "the earth creature"? Genesis 2:7 could therefore be translated: "And Yahweh God formed the earth creature of dust from the earth and breathed into its nostrils the breath of life and the earth creature became a living being."

God then places the earth creature in the garden which God has created and commands the earth creature not to eat from the tree of the knowledge of evil. Through this part of the story the earth creature is on its own and has no specific sexual identity.

In verse 18 God recognizes that the lack of sexual difference causes loneliness in the earth creature. "It is not good for the earth creature to be alone, I will make for it a companion corresponding to it." God creates animals, also from the earth, but these do not correspond appropriately to the earth creature. They are subordinate to the earth creature, as verses 19-20 indicate. Verse 20 is a repetition of verse 18; once again it is emphasized that, "for the earth creature there was not found a companion corresponding to it." So God causes the earth creature to sleep while God takes from it a rib (verse 21): "And Yahweh God built the rib which he took from ha-adam [the earth creature] into issa [woman] and brought her to ha-adam" (verse 22).

The story, which is here told in poetry, then continues (verse 23), clarifying the relationship between the earth creature the two emerging human genders:

And ha-adam said:

This, finally, bone of my bone

and flesh of my flesh.

This shall be called issa [woman]

because from is [man] was taken this.

God's creative work has established two sexually differentiated beings, issa [woman] and is [man], from one sexually undifferentiated being ha-adam [the earth creature]. This becomes even clearer as we read on in verse 24 :

Therefore, a man [is] leaves his father and his mother

and cleaves to his woman [issa]

and they become one flesh.

God begins the creation of human beings with a unity, the earth creature. Two sexually differentiated human beings, a man and a woman, are then produced through a process of separation. And we are then told that it is the purpose of the man and the woman to become a unity again. The story is clear: from unity (the earth creature) through diversity (man and woman) to unity (one flesh). (It is interesting and important to note that the creation story in 
Genesis 1 presents a similar unitary picture of God's creation of human beings.)

Our close reading of Genesis 2-3 does not seem to support the arguments of 1 Timothy. But even if 1 Timothy's reading of Genesis 2-3 was a reasonable reading, ${ }^{3}$ the link between the writer's instructions concerning the role and function of women and this reading is not logical. So where does 1 Timothy get its view of women from? Certainly not from Genesis 1-3. I am not suggesting that Genesis 2-3 is not a patriarchal text; it probably is. But it does not support 1 Timothy's attitude towards women. The writer of 1 Timothy's reading is shaped by the androcentric attitude of his context. Unfortunately, this writer's reading of Genesis 2-3 has become the dominant reading in the church. But we do not have to hear only the dominant (male) readings of the Bible, for our literary analysis of the text has partially tamed it by generating doubts about the author's conclusions from his very own text.

My third and final example comes from a methodological position that locates the meaning of the Bible in the intersection of the text's projected meanings and the reader's horizons of expectation. Such scholars have sought to tame this text by interpreting it in the light of its dominant theological trajectories as they encounter an active reader. A reading of 1 Timothy as a whole suggests that one of the primary themes/symbols/metaphors/ trajectories of the text is "the household of God" (and here I am dependent on the scholarship of Sandra Schneiders (1989)). The text of 1 Timothy was written "so that you will know how people ought to conduct themselves in God's household" (3:15).

This mode of reading assumes that the text of 1 Timothy as we have it in the Bible is relatively independent of the conscious and explicit intentions of its writer. This implies that when we read this text from within the church and community of our time and context the text will often speak to us with more meaning than the author was aware of when he wrote it. Our reading of the text must, however, be in continuity with the direction of the text and must cohere with the totality of the biblical message. So in this example our reading of 1 Timothy is shaped by the central metaphor of "the household of God," the central themes, metaphors, and symbols of the New Testament as a whole, and by the central questions of women in our context.

The life and ministry, the death, and resurrection of Jesus form the basis for the central metaphors, themes, and symbols of the New Testament as a whole. They also form the basis for the central metaphor, "the household of God", in 1 Timothy (3:16). Two key metaphors which emerge from the New Testament as a whole are "discipleship" and "ministry" and these metaphors are components of "the household of God" metaphor in 1 Timothy. But while full discipleship and ministry in the church and community are denied to women in 1 Timothy, women are called by Jesus to full discipleship and ministry in the church and community in the New Testament as a whole and in our present context.

The meaning of "the household of God" metaphor in 1 Timothy is not restricted, according to this mode of reading, to the patriarchal conformities of the writer of 1 Timothy. The metaphor of "the household of God" projects a possible world in which women as well as men are called to full discipleship and ministry in the church and community. This potential meaning is in continuity with the New Testament as a whole, with "the household of God" metaphor of 1 Timothy, and with the concerns of contemporary women.

The author of 1 Timothy restricts the full meaning of "the household of God" metaphor

3. There has been extensive debate among feminist scholars concerning Trible's reading of this passage (see Bal, 1986, Lanser, 1988). 
to men. The psycho-socio-religious world of 1 Timothy would not allow women to fulfil the call of Jesus to full discipleship and ministry. But this text is decontextualized when contemporary women bring new questions to it; it is then recontextualized as it speaks anew to successive generations of believers who faithfully and creatively address new questions to the text in the expectation that the biblical text is indeed living and active. Through this process of decontextualization and recontextualization the text is tamed and women are called to participate fully in the household of God.

\section{The Interpretative Task before Us}

Each of these readings attempts to tame 1 Timothy 2:5-8, though in each case the method used is different. A powerful contribution of biblical scholarship to the more general interpretation of the Bible among ordinary Christian interpreters is precisely the additional resources it offers to the taming task.

But I wonder whether Pastor Lumwira would have been persuaded by any of this? If the call of God to work with a woman could be overruled by this text, will any of our attempts to tame it prove enduringly adequate? As long as patriarchal interests are at stake, it seems to me, they probably will not. But this does not mean that we should give up either on the task of taming such texts or on this text itself. It is naive to imagine that we can ignore this text; as long as it is there in the Bible we must engage with it. If we do not transact with it others will. However, we cannot restrict our ongoing engagement with this text to scholarly journals; we must take it into the public realm. We must contest the current consensus concerning the meaning of this text. We must destabilise the dominant interpretations of this text.

This is the task I have set myself when I write a regular column for our local newspaper, the Natal Witness. Here is an example of my venture into the public realm with this text. In this extract from my article I adopt the metaphor of biblical interpretation as a recipe.

I use the metaphor of a recipe for biblical interpretation because it captures some of the complexity of the interpretative process. Imagine the finished product of a cake recipe. Now try to unravel the flour from the cake before you. You cannot; the flour is an integral part of the cake, and though it was a separable thing when it went into the recipe, it has become indistinguishable from the finished cake. This is a bit like the Bible in our biblical and theological interpretations. We all know what the Bible is before it goes into our interpretative acts, but once we have a "biblical" or theological interpretation it is very difficult to unravel the Bible's role. This is not only because the Bible is but one ingredient in our interpretations, but also because we do not all follow the same recipe in the way we work with the Bible. Let me deal with each of these in turn.

Besides the Bible there are a host of other ingredients that go into the mix that makes up an interpretation. Who we are, our experiences, our interests, our causes and agendas, our denominational backgrounds, our race and gender, our social class, etc. all play roles in our interpretative acts. The Bible does not speak on its own; it requires a reader (or hearer) to activate it, and we are all quite different readers. So the Bible is only one ingredient, albeit a very important ingredient, among many. But, as I have said, this is not the only variable. The ways in which we combine these various ingredients also differs. How much weight, for example, we give to our church tradition and how much weight we give to the Bible will affect our interpretations. When the recipe says "Add Bible and stir", what this means is by no means clear.

Most of us are rather reticent in owning up to the personal and social factors that influence our interpretations. We do not like to admit that being a white male, for example, 
shapes our interpretations of the Bible. So we distance ourselves from such charges by claiming that we are simply "Bible believing Christians" or that we simply believe what "the Bible says" or that we go to "a Bible believing church". Owning up to who we are and accepting that who and what we are may play a role in our biblical and theological interpretations is difficult. So we shift the blame to the Bible! It is now the Bible that "says" that whites are superior to blacks, or that women are inferior to men, or that homosexuals should not be ordained, or that America should bomb Iraq, or that the modern state of Israel owns the land of Palestine, or that parents should beat their children, etc.

But does the Bible "say" such things? Again there is no short answer to this question. Leaving aside the personal, social and denominational factors I have mentioned and focussing on the Bible itself, let us briefly consider the well-known text, 1 Timothy 2:8-15, in which women are instructed to keep silent in church and to learn in silence and submission. What is it that the Bible "says" here? On the surface the text is pretty clear: women must be silent in church and listen to men (in church); their primary purpose is to bear children. But the Bible also "says" that for those baptised into Christ, "there is no longer Jew or Greek, there is no longer slave or free, there is no longer male and female; for all of you are one in Christ Jesus" (Galatians 3:28). So which of these texts has priority? Do we give priority to the earlier text (Galatians) because it was written by Paul himself, whereas the later text (1 Timothy) was probably written by a disciple of Paul's who used Paul's name (a common practice in that time)? Or do we reject such scholarly views and simply accept the later text at face value as written by Paul himself, in which case Paul seems to have changed his mind about there being "no longer male and female"? Or do we prioritise the earlier text precisely because it is closest to the life and ministry of Jesus and therefore probably reflects more closely the vision of Jesus, while the later text models itself on the Graeco-Roman household and is worried that the church Jesus founded is too radical for the conservative views of the world at that time? Or do we try to harmonise the two texts, ignoring issues of when and by whom they were written, arguing, for example, that in some abstract theological sense men and women are equal in Christ (Galatians), but that in practice, in the daily life of the church (1 Timothy), there is still a distinction? Or do we simply ignore one text and concentrate on the other, and if so, which one gets ignored, and who decides?

Our interpretation of this text becomes even more complicated when we read, for example, a few verses later $(3: 2,12)$ that the male minister and deacon in the church must only have one wife. The implication here is that ordinary male members of the church can have more than one wife, though the leadership ought not to. So if we argue that 1 Timothy must guide our Christian practice with respect to women being submissive to men, should it also then guide our practice about the number of wives an ordinary male member of the church may have? ${ }^{4}$

Clearly what the Bible "says" is not self evident, and I have only just scratched the surface of the many decisions we make every time we interpret the Bible, not forgetting the host of personal, social and denominational factors that also impinge on our interpretations. Those of us who are Christians engage with the Bible on such a regular basis that we are probably not conscious of the complex recipes we use to interpret the Bible. But perhaps the time has come for us to be a little more reflective about how we interpret the Bible.

4. One of the hazards of venturing into the public realm is that there is no monolithic public out there! I wrote this article for readers of the Natal Witness, most of whom would be deeply troubled by the idea of ordinary Christians in their churches having more than one wife. However, there are sectors of the public who would applaud 1 Timothy not only for its attempt to silence women, but also for its tacit support for polygamy. 
Perhaps we should be more overt and open about the ingredients that go into our mix and what we then do with the mix in order to produce the cake we consume. We may not agree with each other as a result, but at least we will be able to chart more clearly why we disagree. We may even be less likely to bomb each other. The Bible is a remarkable book, one which Christians believe speaks to us. But perhaps at this time in our history in South Africa we need to be more circumspect in saying "the Bible says" (Natal Witness, 9 November 2002).

\section{A Circumspect Conclusion}

There are no easy answers here. Texts like 1 Timothy 2:8-15 are not easily tamed. Margaret Atwood's harrowing tale of a possible future world in which bits of the Bible are used to ensure that women are only saved (literally) through childbirth (1 Timothy 2:15) and in which this text's other clauses are used to legislate that women should "learn in silence with all subjection" (Atwood 1996:233) is a chilling reminder of just how difficult it is to tame this text. Certainly, Pastor Lumwira was unable to hear the voice of God because of the clamour of this text for attention. Perhaps as we become more adept at hearing God's enabling voice with respect to gender we will pay less attention to the disabling dimensions of this text and its interpretations. Until then, or more accurately, to bring about this "then", we must take up each and every opportunity we get to contest and destabilise - in the public realm of our communities and churches - the interpretations we have inherited and which continue to do so much damage.

\section{BIBLIOGRAPHY}

Atwood, Margaret 1996. The handmaid's tale, Vintage, London.

Bal, Mieke 1986. Sexuality, sin and sorrow: the emergence of female character (a reading of Genesis 1-3), in The female body in western culture (ed. Suleiman, SR) Harvard University Press, Cambridge, pp. 317-338.

Brenner, Athalya 2002. Gendering in/by the Hebrew Bible - Ten years later. Old Testament Essays, 15, 42-51.

Brenner, Athalya and van Dijk-Hemmes, Fokkelien 1993. On gendering texts. Female and male voices in the Hebrew Bible, Brill, Leiden.

Clines, David JA 1995. Interested parties: The ideology of writers and readers of the Hebrew Bible, Sheffield Academic Press, Sheffield.

Draper, Jonathan A 1991. Oppressive and subversive moral instruction in the New Testament, in Women hold up half the sky: women in the church in Southern Africa (eds. Ackermann, D, Draper, JA and Mashinini, E) Cluster Publications, Pietermaritzburg, pp. 37-54.

Fowl, Stephen 1995. Texts don't have ideologies. Biblical Interpretation, 3, 15-34.

Fowl, Stephen E 1990. The ethics of interpretation; or, what's left over after the elimination of meaning, in The Bible in three dimensions: essays in celebration of the fortieth anniversary of the Department of Biblical Studies, University of Sheffield (eds. Clines, DJA, Fowl, SE and Porter, SE) JSOT Press, Sheffield, pp. 379-398.

Hanks, Tom 2000. The subversive gospel: a New Testament commentary of liberation, The Pilgrim Press, Cleveland.

Lanser, Susan S 1988. (Feminist) criticism in the garden: inferring Genesis 2-3. Semeia, 41, 67-84. 
Mosala, Itumeleng J 1989a. Biblical hermeneutics and black theology in South Africa, Eerdmans, Grand Rapids.

--- 1989b. Unpublished paper.

Phiri, Isabel A 2000. African women in mission: two case studies from Malawi. Missionalia, 28, 267-293.

Schneiders, Sandra M 1989. Feminist ideology criticism and biblical hermeneutics. Biblical Theology Bulletin, 19, 3-10.

Sibeko, Malika and Haddad, Beverley G 1997. Reading the Bible "with" women in poor and marginalized communities in South Africa (Mark 5:21-6:1). Semeia, 78, 83-92.

Trible, Phyllis 1979. Eve and Adam: Genesis 2-3 reread, in Womanspirit rising: a feminist reader in religion (eds. Christ, CP and Plaskow, J) Harper and Row, San Francisco, pp. 74-83.

Vaage, Leif E (ed.) 1997. Subversive Scriptures: revolutionary readings of the Christian Bible in Latin America, Trinity Press International, Valley Forge.

West, Gerald O 1993. Contextual Bible study, Cluster Publications, Pietermaritzburg.

--- 1995. Biblical hermeneutics of liberation: Modes of reading the Bible in the South African context, Orbis Books and Cluster Publications, Maryknoll, NY and Pietermaritzburg.

--- 2000a. Contextual Bible Study in South Africa: a resource for reclaiming and regaining land, dignity and identity, in The Bible in Africa: transactions, trends, and trajectories (eds. West, GO and Dube, MW) Brill, Leiden, pp. 595-610.

--- 2000b. Gauging the grain in a more nuanced and literary manner: a cautionary tale concerning the contribution of the social sciences to biblical interpretation, in Rethinking context, rereading texts: contributions from the social sciences to biblical interpretation (ed. Carroll RD) Sheffield Academic Press, Sheffield, pp. 75-105.

--- 2002a. Disguising defiance in ritualisms of subordination: literary and community-based resources for recovering resistance discourse within the dominant discourses of the Bible, in Reading communities reading Scripture (eds. Phillips, GA and Duran, NW.) Trinity Press International, Lewisburg, PA, pp. 194-217.

--- 2002b. Reading abused female bodies in the Bible: interpretative strategies for recognising and recovering the stories of women inscribed by violence but circumscribed by patriarchal text (2 Kings 5). Old Testament Essays, 15, 240-258. 